\title{
(4) 原子カの“グローカル”展開
}

\section{敦賀市 秋田 晶}

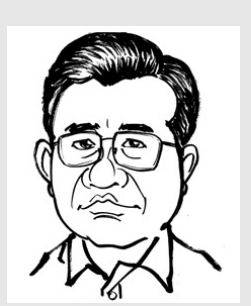

将来を見ないといけません。

敦賀を含む福井県若狭地区には，原子力発電所が 14 基 あります。それらを40年後にコンクリート製のデッカい 墓標にしてしまうのかどうか…私の孫の世代にこの難し い課題が出てきます。それを今から考えることが，私た ちの未来世代への責任です!! 原子炬の廃炉, 解体なんて そう簡単にできることではないですし，仮にできてもそ の跡地利用は難題です。今ある場所とものをもっと有効 に活用していく知恵が必要なのです。

私は，ここ敦賀・若狭地域を，世界の，少なくとも東 アジアの原子エネルギー拠点にするべきだと思います。 いま，福井大学では原子力の国際化を目指しています し, 東京でも新しい大学院の創設や, 学部教育の復活が あります。しかし，国際化の中身がどこまであるのかは 疑問です。少なくとも，私が見る限りにおいて，「もん じゅ」を国際的な研究拠点にするとはいっても，高浜， 大飯，美浜，敦賀などの現行の軽水炉の将来と国際化の 話はほとんど聞こえてきません。原子炬の国際展開も， ものをつくって売り込む話ばかりです。いまある実用に 供しているものも，国際化できるのではないですか。

「もんじゅ」の将来は不透明です。高速炉自体の将来も 同様。私は専門家ではありませんが，30年，40年後に高 速炉が軽水炉に取って代われるとは思えません。40年後 は，遠い未来ではなく，間近なのです。もんじゅの空白 の12年だって，意外にあっというまに過ぎました。

40年後, 現行の敦賀・若狭軽水炉群をいかに活かすか ‥地元から声を上げて考えようではありませんか。そし て，日本，もしくはアジアに貢献できるような原子力拠 点構想へ発展させようではありませんか。

行政の方面からすれば，新しいことを起こそうとする には, 県知事の許可が必要。しかも県知事の許可までに, 幾重にも行政のバリアがある。バリアフリーではないの です。

大学の“国際”, “グローバル”の冠も, 中身はおおむね, 米国や EU の大学や研究所と連携することが, グローバ ル化ということになってはいないでしょうか? 私はロー カルとグローバルをうまくつなぐ，いわば“グローカル” な視点が欠けていると思っています。外ばかりでなく, 内を，地元をみて，そこから世界に持っていけるもの， 世界が注目してくれるものを創っていかなければなりま せん。

敦賀・若狭地区には，加圧水型軽水炉のすべての世代 がそろっています。沸騰水型も高速炉「もんじゅ」もあり ます。今から思えば，新型転換炉「ふげん」が廃炉になっ
たのは実に情けないことす。経済的に合わないという点 では仕方ありません。でも政策的に「ふげん」を単に大間 実証炉への通過点とのみとらえて廃炉としたのが情けな いのです。橋渡しとしての役割がなくなった「ふげん」に 廃炉ではなく，もう一度別の役割を与えて活かす，とい う発想転換が必要だったのです。しかし，当事者の動燃 はもちろん，学者も何も発言せず，他人事のように傍観 した末の廃炉。「もんじゅ」が同じ末路をたどらない保証 がありますか。軽水炉群の末路も透けて見えてきます。

さて，残った敦賀・若狭軽水炉群を廃炉にするわけに はいきません。『廃』という言葉には，負のイメージ，壊 れた，役立たず，悪いものというイメージがつきまとい ます。過去40余年前, 地元は誘致時に村を二分する運動 に懊悩し，運転開始後は，様々な故障や事故と遭遇し， そのたびに風評被害と戦ってきました。その, 原子炉群 とつきあってきた地域社会の記憶や経験，さらに，原子 炬の保守メインテナンスのノウハウ, 原子炬群そのも の，それらを総合し，グローカルに活かす。これが私の 考える『敦賀・若狭原子エネルギー拠点構想』の理念です。

2020年までに 9 基新設するといいますが，新たに立地 の用地を獲得するのは夢物語だと思います。いまあるも の, 老朽化していくものを大切にし, ポジティブなイメー ジと価值を創り出す。それがアカデミックな人たちの責 任でもあると思います。

社会と科学技術ということでいえば, その最先端を 走っているのが原子力です。しかし，その認識がなく， 暗く悲しい話ばっかりしている現実に立地地域の私たち は怒りさえ覚えます。10数年前にケープカナベラルに行 きました。まるで観光地のように見学料を取っていまし た。最先端の科学技術がこれでいいのかと，違和感があ りました。が，少しして，これだと思いました。こうい う発想の転換が必要だと。日本人は，ものづくりと同時 にものを大切にしてきました。廃炉という負の遺産にせ ず，光り輝く活力源にするために皆さんの知恵を貸して 頂けませんか。そうでないと，“もったいない”と思いま す。

また同時に，敦賀短期大学に原子力の研究センターを 併設できないかとも思います。折角ある大学を活用して 今以上に地域に役立てないと大変もったいないと思いま す。

（2009年 8 月19日 記）

秋田 晶(あきた あきら)

敦賀市蓬莱町『侏秋田船具店』社長。戦前より, 敦賀港で船具 商を行う。家族は, 家内と息子 1 人・娘 2 人。 趣味：旅行 